\title{
Path Dependency and Future Adaptation of Coastal Cities: Examples From the Asia-Pacific
}

\author{
Patrick D. Nunn ${ }^{1 *}$, Timothy F. Smith ${ }^{1,2,3}$ and Carmen Elrick-Barr ${ }^{1}$ \\ ${ }^{1}$ Sustainability Research Centre and Australian Centre for Pacific Islands Research, University of the Sunshine Coast,

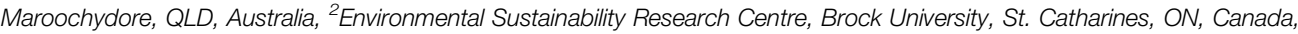 \\ ${ }^{3}$ SWEDESD, Uppsala University, Uppsala, Sweden
}

OPEN ACCESS

Edited by:

Craig E Colten,

Louisiana State University,

United States

Reviewed by:

Elzbieta Antczak,

University of Łódź, Poland John W Day,

Louisiana State University,

United States

*Correspondence:

Patrick D. Nunn

pnunn@usc.edu.au

Specialty section:

This article was submitted to

Land Use Dynamics,

a section of the journal

Frontiers in Environmental Science

Received: 16 December 2020

Accepted: 10 August 2021

Published: 24 August 2021

Citation:

Nunn PD, Smith TF and Elrick-Barr C (2021) Path Dependency and Future Adaptation of Coastal Cities: Examples

From the Asia-Pacific.

Front. Environ. Sci. 9:642385.

doi: $10.3389 /$ fenvs.2021.642385
The need for Asia-Pacific coastal cities to adapt effectively and sustainably to accelerating (relative) sea-level rise is growing. If such adaptation does not occur in a timely manner, then it could result in socio-economic problems that will reverberate throughout the region. Using examples of coastal Asia-Pacific cities that are characterised by contrasting geographical settings and cultural contexts, this study argues that the main barrier to such adaptation is path dependency. In this sense, path dependency is a legacy of past decisions that have been influenced by topography, economic goals, and the culturalpolitical characteristics of key decision-making groups. These path dependencies manifest as various adaptation preferences, which to date have been dominated by hard engineering solutions. In an era of accelerating climate change there is now a need to seek alternatives to in-situ urban growth. This paper argues that an understanding of a city's path dependency is key to optimizing the effectiveness of future adaptation.

Keywords: coastal management, climate change adaptation, path dependency, urban futures, sea-level rise, urbanization, sustainable futures

\section{INTRODUCTION}

All the world's large cities face challenges of sustainability in the future, many arising from rapid rates of recent growth in which economic development has been preferenced over issues affecting quality of life such as water management and pollution, amenity provision and overcrowding, homelessness and unemployment (Feng et al., 2020; Sadr et al., 2020). In all cities, future climate-driven livelihood and economic stressors will aggravate these issues, making the challenge of sustaining viable cities greater than might otherwise be the case (Revi et al., 2014). And while more immediate management concerns arise from the effects of COVID19, the longer-term challenges from climate change remain and are expected to last far longer, probably well beyond the year 2100 for coastal cities affected by rising sea level.

Every large city faces climate-linked challenges that are unique, deriving from its location, its form and density, and from the activities that have sustained its recent development. Less obvious yet often of equal importance is a city's historical development, sometimes going back centuries, that have controlled the way in which it grew (Arden and Jawitz, 2019; Moreno, 2020). This is a function of both geography and of the oversight for such development, which will vary considerably depending on whether it takes place in, for instance, a capitalist or a socialist setting or a democratic or an autocratic one (Qian, 2015; Slaev et al., 2018). The historical decisions that affect social, economic and environmental conditions have set various courses of action which are manifested today through urban development, social norms, levels of social-ecological resilience, and dominant responses to 
threats. This is referred to as path dependency and we argue in this study that an understanding of this is key to identifying sustainable futures for large cities, a point we illustrate by looking at five Asia-Pacific cities in diverse contexts.

The next section reviews the history of urbanization in the AsiaPacific region and outlines the broad challenges to future urban sustainability therein. Then we discuss the phenomenon of path dependency and review its influence on planning for climatelinked adaptation. Then we present examples of five Asia-Pacific cities with contrasting development histories and climate exposure, and discuss past and planned approaches to adaptation.

\section{ASIA-PACIFIC URBANIZATION AND ITS SUSTAINABILITY}

Some of the world's earliest "cities" were established in East Asia (Renfrew and Liu, 2018). The constant land loss and developmental stresses imposed on coastal societies (and their complexification) during the period of postglacial sea-level rise (15,000-5,000 years ago in most places) ended about five thousand years ago, paving the way for the development of large/urban coastal settlements in many parts of the AsiaPacific region (Day et al., 2007; Day et al., 2012). Lawler (2014) documents several recent discoveries of maritime sea routes and trading settlements that existed around $400 \mathrm{BCE}$.

Compared with many other parts of the world, the Asia-Pacific region has a disproportionately high number of large cities on the coast. These cities are located mostly around river-mouths and signify the importance of long-distance over-sea trade in the region, which intensified over the last 500 years. Examples include Manila (Philippines) that was the entrepôt in the "East Indies" favored by most European powers, Kochi (India) from which pepper and spices reached Europe, and Macau (China) through which Portuguese trade with China, Japan and the Malaccas (Indonesia) was driven for centuries (Malekandathil, 2013; Ebrey and Walthall, 2014). The nature of urbanization across the Asia-Pacific region followed a similar trend to that elsewhere in the world until about 150 years ago when ideologies started to influence development trajectories. Yet the legacy of sustained sea-trade is the proliferation of urban areas in the AsiaPacific region that are increasingly prone to coastal climate hazards through both their geographic location and continued population growth (Chan et al., 2012; Smith et al., 2013).

Driven by an abundance of cheap energy, an acceleration in growth of urban populations in the Asia-Pacific region began around 1950 at which time less than $15 \%$ of its population was urban, a contrast with today when more than $50 \%$ of the region's population resides in urban areas, a trend projected to continue (Burger et al., 2018; Kundu et al., 2020). Yet the recency of urbanization varies within this region, with many East and Southeast Asian urban areas developing extremely rapidly from 1975 compared to Australia and New Zealand that experienced urbanization decades earlier (Guneralp et al., 2020). The delay (in some cases periodic decline) in urbanization in East and Southeast Asia has been attributed to the influence of totalitarian or communist regimes in several countries, particularly between the 1960s and 1980s. For example, the population of Cambodian cities declined by almost $60 \%$ when the Khmer Rouge took power in 1975 and forced urban populations into rural areas. Yet in Cambodia, since the transition towards democracy and neo-liberal ideologies, and the accompanying easing of internal mobility restrictions, rural to urban migration has soared. China has also experienced rapid urbanization over the past 40 years, facilitated by its transition towards a market economy, especially the rise of manufacturing, and centralized development initiatives (Friedmann, 2011; Chen et al., 2013). Similar trends have been experienced in the Pacific Islands; for example, Haberkorn (1992) found that $7 \%$ of Melanesia's population was urban in 1955 , increasing to $20 \%$ by 1985 , driven primarily by internal population mobility. Yet there is still considerable variation in urban population proportions in the Pacific, some countries like Fiji (where wage employment opportunities are comparatively high) having pre-COVID more than $50 \%$ of its people living in urban areas compared to countries like Samoa where just $18 \%$ of people live in urban areas (Keen and Connell, 2019).

Urbanization in many Asia-Pacific contexts has been sustained by the continued availability of cheap energy to power industry and production (Burger et al., 2018), which has left them with an outsized carbon footprint. As Lee comments, "the economic growth, exports, industrialization and urbanization of the developing countries in Southeast Asia have been achieved at the cost of increasing the carbon footprint of the region (implying) that the environmental policies of the export-led growth countries never have been effective so far since the nations have achieved their economic growth at the high cost of harming the environment" (Lee, 2019: 398).

With over 2.3 billion inhabitants, East and Southeast Asia is home to about $30 \%$ of the world's population. Yet while population growth is expected to continue until about 2050, it is also projected that the population of the region will have declined by $16 \%$ by 2100 (UN, 2019). In contrast, while Australia and New Zealand's combined population is only 30 million, it is expected to grow $63 \%$ by 2100 . The rest of Oceania has a current population of 12 million people and is projected to grow by $117 \%$ within the same period. Overall, the proportion of urban dwellers in the Asia-Pacific is projected to remain stable or continue to grow (Attane and Barbieri, 2009).

Pre-COVID changes in the Asia-Pacific population are driven primarily by changes in fertility and mortality rates, although migration attributable to conflict and labor movements is an important factor, especially in terms of rural-urban migration For example, Myanmar has lost 1.3 million people owing to insecurity and conflict over the past decade while Bangladesh and the Philippines have lost 4.2 million and 1.2 million respectively as a result of temporary labor movements (UN, 2019). In contrast, Australia's population has been regularly increased by international migration. The long-term impacts of COVID19 on trends of population growth and decline in the Asia-Pacific region are as yet uncertain although there is mounting anecdotal evidence of urban-rural movement since the start of the pandemic, attributable to loss of wage employment in urban areas and the possibility of living more cheaply, 
particularly on traditional lands, in rural areas (Panwar and Mishra, 2020).

Notwithstanding the current uncertainties regarding internal migration driven by COVID19, in several parts of the Asia-Pacific region, urbanization driven by economic and population growth, industrialization and rural depopulation has fuelled the rapid growth of "megacities" that are recognized as exhibiting particular challenges for future sustainability, especially in coastal locations where climate-change impacts have been (and are expected to be) particularly pronounced (Georgeson et al., 2016; Hinkel et al., 2018). For example, the liveability of China's megacities like Beijing and Shanghai has been challenged by recent heatwaves, their unprecedented severity and duration attributable to climate change, exacerbated by heat-island effects (Yu et al., 2018). In Metro Manila (Philippines), the increasing incidence and extent of urban flooding is attributable to both sea-level rise (amplified by land subsidence) and changing patterns of storminess, both likely results of climate change (Meerow, 2017; Doberstein et al., 2020).

All these region-specific impacts will be overprinted by global climate stressors, including shifts in the human temperature niche (Xu et al., 2020), more extreme heatwaves and wildfires (Mora et al., 2017; Robinne et al., 2018), stronger tropical cyclones and extreme precipitation events (Min et al., 2011; Power et al., 2017; Hinkel et al., 2018). It is also worth noting that coastal locations are expected to be disproportionately impacted by both global/regional climate stressors in the future, especially in low latitudes. This is not only because coastal livelihoods (and the infrastructure on which they depend) are more exposed along coastlines but also because many coastal cities in the low-latitude Asia-Pacific region have for several decades been experiencing comparatively complex challenges to their sustainability arising from their low-lying locations, such as exposure to extreme events associated with low-latitudes like tropical cyclones and heatwaves (Tessler et al., 2015; Day et al., 2018).

Climate change is showing signs of accelerating in the AsiaPacific region and is expected to be a massive stressor on urban life by the end of this century, not least because global temperatures may average $2-4^{\circ} \mathrm{C}$ higher and global mean sea level may be over $1 \mathrm{~m}$ higher than today (IPCC, 2018; Horton et al., 2020). For many of the world's megacities, plans have already been drawn up to adapt to the clearest and most damaging effects of 21st-century climate change, ranging from the relocation of Jakarta (Indonesia) to the managed retreat of several North American cities (Carey, 2020).

Increased sensitivity to extreme events in coastal cities will be exacerbated not only by increases in population generally but also by an increasingly ageing population. Globally, in 2018, those aged 65 years and over outnumbered those aged under five for probably the first time in human history; from 2019 to 2050, the average life expectancy is likely to increase from $72.6-77.1$ years (UN, 2019). In the Asia-Pacific region, the proportion of people aged over 65 years is projected to increase in 2050 by $171-30.4 \%$ of the total population in East and South East Asia; by 80-28.6\% of the total population in Australia and New Zealand; and by a massive $267-15.4 \%$ of the total population in the rest of Oceania
(UN, 2019). This will not only place a massively increased strain on urban services but also a reduction in per capita economic activity (Tong et al., 2015).

To some degree, an increase in sensitivity of Asia-Pacific urban conurbations to extreme events may be offset by improvements in adaptive capacity, and there are several indicators showing that adaptive capacity has increased rapidly in this region over the past 50 years. For example, Attane and Barbiere (2009) show that literacy rates dramatically increased in East and Southeast Asia from 1980 to 2005 (e.g. in China, illiteracy dropped from 32.9\% of the population to $11.8 \%$ ); literacy makes communication easier, facilitates the spread of understanding, and can lead to adaptive actions that may be far more difficult to achieve when most stakeholders are non-literate. In addition, as Gallopín (2020) recently argued, future opportunities for urban sustainability are also afforded by the growing dissipation of urban functions, including long-distance supply of energy, the global sharing of information, and even the outsourced production of traditional urban materials. In such a situation, in which a city is losing entropy and having its environment disorganized, the question arises as to what a "sustainable city" might look like.

\section{PATH DEPENDENCY AND ITS INFLUENCE ON ADAPTATION PLANNING}

Since the 1970s, path dependency has been used by various disciplines to describe a constrained future option/s based on a previous decision/s. For example, Hohn and Schneider (1991), (p 111) show that "critical decisions, historical accidents, exogenous shocks and situational coincidences" shape a certain development pathway. In other words, path dependency refers to the reduction in the portfolio of options based on prior choices and conditions. When applied to adaptation to global change, investments in capital are made and thus promote continued investment to avoid loss of capital (Barnett and O'Neill, 2010). Contracts are established and need to be honored (Runhaar et al., 2012). Or more broadly, manipulative behaviors are adopted to maintain the status quo (Thomsen et al., 2012). Strategies to maintain the status quo, whether to avoid losses in capital investment or to appeal to social norms, lessen the probability of effective adaptation by creating adverse path dependencies "whereby each manipulative action increases social-ecological stress, reduces adaptive capacity, and necessitates continued manipulative actions in order to avoid changing the dominant social paradigm" (Thomsen et al., 2012, p 23). In contrast, systems approaches to adaptation that take both a broader and longer-term view of both the system under threat and the goals of adaptation, and guided by principles such as those outlined through a sustainable livelihoods lens (e.g. inclusivity, long-term poverty reduction, ecosystem stewardship, building of capacity and agency) are less likely to lead to path dependencies (Smith et al., 2013).

Diverse adaptive responses have been identified as a mechanism to reduce path dependency by broadening the range of available options using, for example, a combination of prevention, defense, mitigation, and adaptation strategies. Yet 


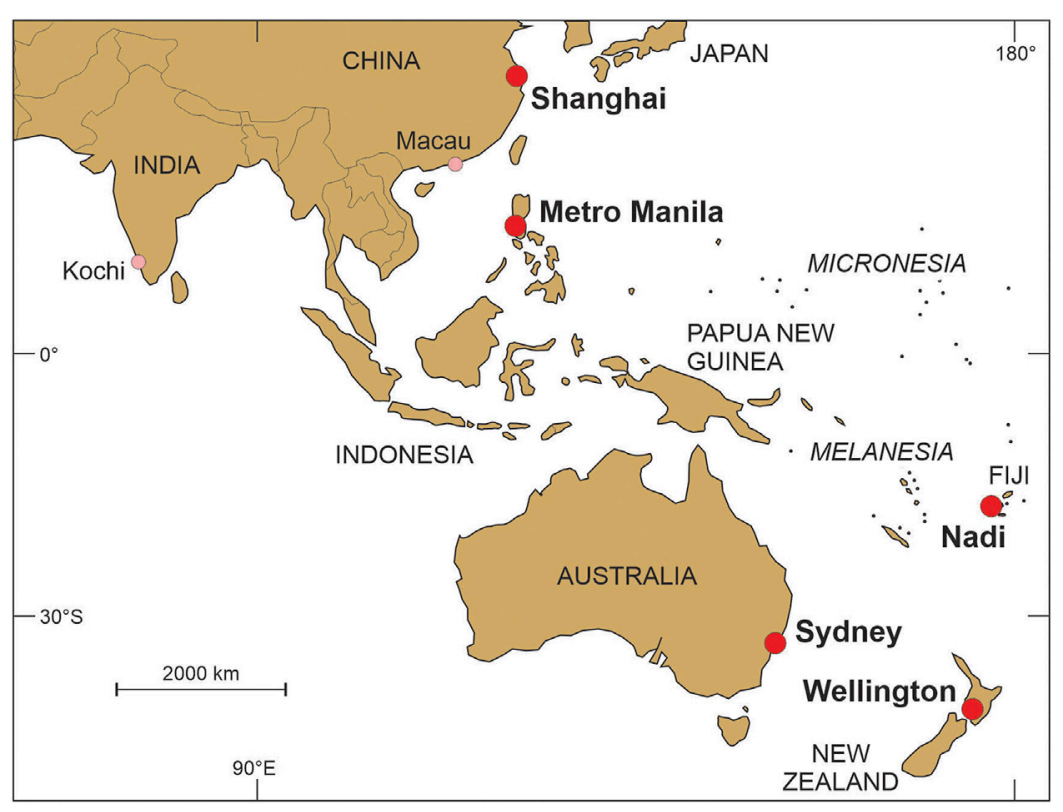

FIGURE 1 | The Asia-Pacific region showing the five case study sites (bold) and other places mentioned in the text.

a study of flood risk management in Europe found that while path dependency was indeed high in countries where certain risk approaches had traditionally dominated (e.g. flood defense in the Netherlands), they also uncovered path dependency in countries with more diversified approaches (e.g. England and France) (Wiering et al., 2017). Additional considerations must therefore be taken into account to better understand path dependencies. For example, Stern (2006), (p 381) states that "individuals and firms behave habitually and in response to social customs and expectations. This leads to path dependency, which limits their responses to policies designed to raise efficiency". Shove (2010) adds that flexibility is not a usual trait of societal systems and that, only through the realization of vulnerability or a disastrous (trigger) event, is transformation possible.

Smith and Smith (2006) likewise highlight that committing to a learning framework may overcome path dependencies through institutionalizing continuous improvement for coastal sustainability. Furthermore, learning based on an understanding of the weight of the past, the push of the present, and the pull of the future (Inayatullah, 2008), combined with systems understanding, reduces the potential for decisions that will lead to path dependencies (Smith et al., 2013). Thus, a better understanding of these considerations for coastal cities in the Asia-Pacific region, which are exposed to significant coastal hazards, increasing both in intensity and frequency, is required if they are to continue to prosper.

\section{CASE STUDIES}

Here we briefly summaries the historical context, past approaches to adaptation, planned adaptations and adaptive capacity of five
Asia-Pacific cities: Shanghai (China), Metro Manila (Philippines), Nadi (Fiji), Wellington (New Zealand) and Sydney (Australia). The case studies provide examples of the nature of pathdependency in various contexts. The case studies were selected to illustrate commonalities and differences in approaches in a range of geographical settings and cultural contexts throughout the region (Figure 1).

\section{Shanghai, China}

Shanghai is situated between the East China Sea, the Yangtze River Estuary, and Hangzhou Bay, bordering the Jiangsu and Zhejiang provinces (Yin et al., 2013). Since 1979, Shanghai has undergone rapid urban development, initiated by the government's "reform and opening-up policy" in 1978 and "opening Pudong new area to the world" in 1990 (Yin et al., 2011). Shanghai is now the largest economic center in China, where $85 \%$ of land is urbanized (housing a population of over 27 million people, with a population density of more than 2,059 people per square kilometer). Rapid population growth and ruralurban migration has driven significant land reclamation in Shanghai. Between 1949 and 2010, over 1,000 square kilometers of the coastal wetlands in the Yangtze Estuary was reclaimed (Mi et al., 2016).

Today, Shanghai city center is situated on the lowest floodplain of the city (Xian et al., 2018). It is vulnerable to flooding from both extreme events (e.g. typhoons) and sealevel rise (Wang et al., 2012). Land subsidence, both tectonic and compaction (resulting from groundwater extraction, highrise construction and population growth), has contributed significantly to the rise in relative sea level. By 2070, it is anticipated that Shanghai will have more than 5.4 million people, and assets to the value of $\$ 1771$ billion, exposed to coastal (river + sea) flooding (Xian et al., 2018). 
The dominant approach to adaptation in Shanghai has been protection through the construction of sea walls (Bao et al., 2020); some of the earliest "hard" structures to prevent flooding were constructed in this region around 5,000 years ago (Liu et al., 2015). Today, Shanghai's developed coastline is protected by sea walls with a 200-years coastal flood return design. The implementation of protective measures has followed impacts of extreme events. For example, the "63 standard" for flood defense (specifying a minimum height for sea walls) was introduced following a 1962 flood event that destroyed 1,500 houses and killed hundreds of people. Later events saw the introduction of the "74 standard", and later still, the " 84 standard" (requiring a design for the 1000-years flood level) which remains in use (Xian et al., 2018).

Despite these improvements, Wang et al. (2012) report that the existing 6-m-high flood-control walls are insufficient to address the combined effects of sea-level rise, land subsidence and storm surge. They estimate that by 2100 , half of Shanghai will be regularly flooded and $48 \%$ of the length of current sea walls in Shanghai may be overtopped. Their findings are supported by Cheng and Chen (2017) who noted that raising the sea-wall standard from one-in-100-years flood height to one-in-200-years flood height was required to address risk from rising sea level combined with land subsidence.

The uptake of adaptation in response to sea-level rise has been slow (Cheng and Chen, 2017). This is in part attributed to limited forward planning in relation to climate risks (Xian et al., 2018). Despite this, Shanghai is implementing planned responses to address current climate risks, such as extreme flooding. For example, in 2016 Shanghai joined the Sponge City Initiative (Zevenbergen et al., 2018), an initiative with a target of $20 \%$ of urban areas absorbing, retaining, and reusing $70 \%$ of rainwater by 2020 . By 2030 , this percentage should increase to $80 \%$. To achieve these targets, cities are investing in permeable pavements, artificial ponds and wetlands, and rain gardens to store excess rainfall. The required investments to achieve the ambitious targets are estimated at 100-150 million RMB per $\mathrm{km}^{2}$ (16-24 million USD per $\mathrm{km}^{2}$ ) in Shanghai.

Recognizing the exposure of its coastal cities, China has demonstrated significant capacity to rapidly implement reforms to address climate risks (as seen for example via the Sponge City initiative). Shanghai's rapid economic growth and significant economic position, and higher level of autonomy than other cities within provincial and central administrations, means it has the financial capacity and political commitment to implement large-scale infrastructure development. Furthermore, alignment between central and local governments allows for rapid consensual governmental decision-making yet there is little evidence of capacity for bottom-up and/or autonomous adaptation initiatives (Yin et al., 2011; Xian et al., 2018).

\section{Metro Manila, Philippines}

Located on the western side of Luzon Island, the sixteen cities (and one municipality) comprising Metro Manila are mostly coastal, either facing west to Manila Bay or east alongside the (lake named) Laguna de Bay; half occupy the narrow neck of land between the two. Metro Manila is currently home to some 12.8 million people, at least 700,000 of whom are informal settlers. Land reclamation for coastal defense unintentionally serves to provide additional land for informal settlements (Valenzuela et al., 2020).

The Philippines is one of the world's most disaster-exposed countries (De Leon and Pittock, 2017). In Metro Manila, the most common natural hazard is flooding, which typically occurs at times of unusually heavy rain, as is often associated with tropical cyclones (typhoons). Around half the area of Metro Manila floods during such events, which have become more severe (more common and enduring) in the 15 years. Typhoon Ondoy (or Ketsana, September 2009) involved $450 \mathrm{~mm}$ of rain in $12 \mathrm{~h}$, a 40 year record (Abon et al., 2011); flood depths in parts of Metro Manila were around $7 \mathrm{~m}$. More frequently, monsoon rains (habagat) are the main cause of yearly flooding here.

Strong typhoon winds also represent a distinct hazard, as do the landslides that most commonly affect those elevated, often steep land, parts of Metro Manila which are not commonly affected by flooding (Bankoff, 2003). The Manila (sea-floor) Trench that lies west of Luzon is the site of occasional earthquakes, some of which could generate tsunamis that would impact Manila (Ren and Liu, 2015). Sea-level rise is also expected to impact Metro Manila significantly, with estimated annual damage costs of up to US $\$ 6.3$ billion; accounting for $98 \%$ of the expected sea-level rise induced damage costs for the entire country (McLeod et al., 2010). The effects of sea-level rise are worsened by human-induced land subsidence resulting from excessive extraction of groundwater (Rodolfo and Siringan, 2006).

In 1991, the national government decentralized fiscal and administrative responsibility to local governments. As a result, planning power was passed to city and municipal governments, where powerful land-holding families held strong political influence and privatized land use planning - a situation particularly evident in Metro Manilla (Mitchell and Laycock, 2019). Privatization has hampered environmental and hazard management efforts, whilst also increasing the divide between rich and poor (Mitchell and Laycock, 2019).

Like many rapidly-growing coastal cities in which relocation, even risk-informed planning, has been regarded as antithetic to development (and economic growth), Manila has tended to respond reactively to flooding events by building solid sea defenses (De Leon and Pittock, 2017). At the national level, the need to integrate climate change adaptation planning with disaster risk reduction has been recognized through, for example, an agreement between the Disaster Risk Reduction Management Council and the Climate Change Commission; and a People's Survival Fund (established in 2012) to provide long-term financing to local government and communities to implement climate change adaptation projects. Yet De Leon and Pittock (2017) note that a long-term and integrated approach to planning for climate change and natural hazard risk is yet to be developed, with a focus on technological, short-term, project-based approaches: a situation common when adaptation and disaster management responses are led by donor partners, as is the case in the Philippines. 
The favoring of short-term incremental (rather than longerterm transformational) interventions for climate-change adaptation in Metro Manila is also explained by "highly bonded social capital" reinforced by a culture of awareness and decision-making that is siloed and incompletely informed (Laycock and Mitchell, 2019).

It has become clear that in Metro Manila the "sole reliance on traditional 'hard' engineering or structural measures is now insufficient for flood hazard control" (Mercado et al., 2020: 1) implying that relocation of people and infrastructure from the most exposed areas is increasingly recognized as the only longterm sustainable solution. Relocations have previously occurred but most have been temporary, displaced residents returning to their former abodes once they become habitable again. Many residents favor building upwards but most do not entertain resettlement beyond the city; in a recent survey, "no interviewee identified any possible solutions to the political challenges for resettlement in Manila" (Tadgell et al., 2017: 456).

Yet there is a growing awareness of a need for bold high-level strategic interventions in Metro Manila to build its resilience, something which requires not merely on-ground action but also "incremental shifts to existing social capital" (Laycock and Mitchell, 2019: 47), in other words developing a will to transform livelihoods. To this end, "managed retreat" has been repeatedly proposed in Metro Manila although several barriers-including land availability, livelihood loss, and corruption-continue to hinder its implementation (Doberstein et al., 2020).

National challenges involved in sustainable economic development are well illustrated for the Philippines, given its rapidly growing economy (pre-COVID19) and its escalating exposure to disaster. For example, the Philippines was the fastest-growing economy in Asia in 2015 but also ranked 33rd out of 48 countries in the region in terms of water security, something that reflects the country's "inability to give water security the same level of importance as economic development" (Lee et al., 2020: 1). This is a common situation, especially in Asia-Pacific cities, exacerbated in the case of Metro Manila by both droughts associated with El Niño events and an outdated (inadequately-maintained) water-supply infrastructure.

At a city level, several authors have proposed that the major cause of flood management in Metro Manila is the institutional governance framework, specifically the absence of a governing body with sufficient power to overrule competing (economic) interests to develop and direct appropriate disaster risk reduction management plans (Laycock and Mitchell, 2019; UNDRR, 2019). Such an impotency of governance, which is clearly displayed in the aftermath of disasters such as Typhoon Haiyan (or Yolanda, November 2013), also points to the inability of national government to translate policy into resilience-building at the community level (Walch, 2018).

\section{Nadi, Fiji Islands}

Nadi is located on a coastal delta-edge on the west coast of Viti Levu, the largest island in the Fiji archipelago (Southwest Pacific), and grew in the early decades of the 20th century as an entrepôt for agricultural exports from the fertile Nadi River Basin and imports to sustain the area's growth and importance to the colonial government. Nadi was formally declared a township in 1947 and is currently home to around 45,000 people. Today, Nadi is Fiji's principal tourism hub, a commercial, recreational and light-manufacturing center sustained largely by the 900,000 visitors each year (pre-COVID19) who pass through the adjacent Nadi International Airport. Although Nadi lies within the Viti Levu rainshadow, it receives an average $1900 \mathrm{~mm}$ annually, mostly in summer and commonly associated with tropical cyclones.

Much of Nadi is flood-prone, a result of combined delta subsidence and sea-level rise currently around $4 \mathrm{~mm} /$ year (Nunn, 2013) and it seems clear that the nature and pace of recent coastal developments here is incompatible with the accelerating rate of climate change (Bernard and Cook, 2015; Chandra and Gaganis, 2016; Nerem and Fasullo, 2019). In particular, the subsidence-enhanced effects of sea-level rise on the Nadi fringe and the projected increase in average tropicalcyclone strength both signal the need for transformative adaptation of functionality and production in the Nadi area, as elsewhere in the Pacific Islands region (Nunn and McNamara, 2019).

Most of the adaptive measures undertaken in the Nadi area to reduce flooding in the past have been predicated on the belief that the problems are principally caused by poor land and urban management-and that these problems can therefore be corrected by improving practice. While this is consistent with the culturally-grounded short-term outlook common in several Pacific Island societies (Nunn, 2009), it is also a response to the belief that effective adaptation is costly and that it should be avoided for that reason; in other words, cash is scarce and should not generally be allocated to non-revenue generating activities. So as in many poorer contexts elsewhere in the world, the response in Nadi to flooding has been minimalist, low-cost and incremental (Kates et al., 2012).

In the belief that unspecified deforestation of the hinterland (which was actually denuded more than a century ago) caused infilling of lowland river channels, diesel dredgers have regularly been deployed without any clear understanding of sediment dynamics and the effects of sea-level rise on this (Nunn, 2013). In the belief that the town drainage (storm runoff) system was not functioning properly, a major revitalization was undertaken (McNamara, 2013). And coastal (tourism) developers who cleared mangroves, exposing soft-sediment coasts in Nadi Bay to wave erosion, to reclaim land have often had to spend significant funds to construct unsightly sea defenses (Bernard and Cook, 2015).

The usual practice of Pacific Island governments, with commonly little discretionary funding, is to appeal to donors for finance to underwrite the costs of climate-change adaptation (Nunn and Kumar, 2019). A good example of this in Nadi has been an ambitious scheme to divert the course of the lower Nadi River, moving its mouth several kilometers further away from Nadi Town. The Government of Japan, a major donor partner of Fiji, undertook studies that suggested this would significantly reduce flooding of Nadi Town; the reasons for this deduction are unclear but the likely assumption is that terrestrial sediment 
accumulation in lowland river channels is the main cause of recent increases in flood frequency, magnitude and extent. This is unfortunate, especially as there is compelling evidence that a sealevel rise of at least $4 \mathrm{~mm} /$ year is likely to be the principal cause of increased flooding in Nadi. The Japanese Government initially promised to fund the river-mouth diversion project but have recently pulled back from doing so. The only effective and sustainable solution is to relocate Nadi Town, at least its lowest and most vulnerable parts (Nunn and Kumar, 2019).

Among the independent island nations of the Pacific, there is little appetite for costly disruptive transformational adaptation to future climate change of a kind that academics and others are increasing recognizing as necessary to avoid far more costly and disruptive incremental adaptation (Klöck and Nunn, 2019; Nunn and Kumar, 2019; Nunn and McNamara, 2019).

In the case of Nadi Town, a preference for continued in-situ adaptation is still expressed, with year-by-year repairs made to infrastructure and businesses on the unspoken assumption that the situation will eventually get better. This attitude can be ascribed to pragmatic denialism but in a Pacific island context it is also important to acknowledge the role of faith-based beliefs (Nunn et al., 2016). Faith underlies national, community and individual self-belief across the Pacific region and has commonly been cited as a reason for what outsiders invariably perceive as "climate inaction"; in several Pacific Island nations-climate projections involving continued sea-level rise are often denied on the grounds they run contrary to God's promise not to flood the earth anew (Kempf, 2017). New approaches meshing religious beliefs with science-based projections hold considerable promise (Fair, 2018).

In urban centers like Nadi, it is likely a tipping point will be reached at some future time when, perhaps as a result of the lowest part of Nadi being permanently underwater for several months, it will be realized by authorities (and their donor partners) that in-situ adaptation is no longer a rational future option. This will force transformational adaptation, in this case the relocation of key functions to the Nadi hinterland (Nunn and Kumar, 2019; Nunn and McNamara, 2019).

Urban centers like Nadi that are facing growing and profound challenges from climate change have little inherent capacity to counter associated risks, just as the government that oversees Nadi's development has insufficient resources of its own to solve these challenges. Costly interventions must be funded by Fiji's donor partners or the international community, an approach that in the past has seen donor agendas and understandings privileged, often to the detriment of the effectiveness and sustainability of interventions (Nunn et al., 2020).

Yet countries like Fiji have a degree of innate resilience that can help communities-and even urban centers like Nadi-cope with climate change and disasters (Korovulavula et al., 2019; Nunn and Campbell, 2020). So it is conceivable that communitybased organizations to which various groups of Nadi residents belong will drive transformational adaptation in the future.

\section{Wellington, New Zealand}

Wellington was settled by Māori people prior to the 12th century and colonialized by Europeans from 1840. In 1865, Wellington became New Zealand's capital, facilitating its growth as a commercial and administrative center. Wellington is currently the second largest city of New Zealand and the Wellington region has a population of over 500,000 people.

Wellington's development has been markedly shaped by its geography. Situated on the southern tip of New Zealand's North Island, the waters of Cook Strait to the east and south, and mountain ranges to the west and north, limit the availability of flat land, most of which was developed by 1911. For almost a century until the demise of manufacturing, the harbor was the heart of the city, but became a redundant waterfront in the 1970s and early 1980s. With the loss of manufacturing employment, growth has been in the financial services sector and, despite the growing dominance of the business sector in Auckland, Wellington retains its role as a commercial center as well as the seat of national government in New Zealand.

New Zealand lies on the boundary between the IndoAustralian and Pacific tectonic plates; and the Wellington region is crossed by a number of major faults, including the Wairarapa, Wellington and Ohariu faults. Consequently, the region has been subject to a number of large earthquakes, including an 8.2 magnitude quake in 1855, which damaged the city and uplifted parts of the harbor, and in November 2016 when a 7.8 magnitude quake caused damage to buildings throughout the region (Kurashimo et al., 2015). Tsunami risk is high, as is flood risk. In addition, the region is exposed to storms, with New Zealand lying in the path of the strong westerly airflow known as the roaring forties. In addition, the North and South Island mountain ranges funnel winds through the Cook Strait, which results in extreme wind conditions. Projections suggest increased risk to coastal roads and infrastructure from coastal erosion and inundation, increased storminess and sea-level rise (Reisinger et al., 2014; Cagigal et al., 2020).

Wellington has historically adopted hard defense options to respond to sea-level rise and other coastal hazards. Pressure placed on local governments by developers or private property owners is the principal driver for this response, with councils having capitulated to the protection of private property in the face of coastal inundation. This has led to a "legacy of development, including long-lived infrastructure, exposed to increasing climate risks that will create ongoing costs and liabilities for councils" (Manning et al., 2015, p 588).

Having regard for the effects of climate change is now a statutory requirement in New Zealand, one primarily overseen by local government. Local government action is informed by a National Coastal Policy Statement and documents describing risk-based approaches to respond to sea-level rise and flood risk. Yet there have been variable responses across local governments in the country (Lawrence et al., 2019).

In August 2019, the Greater Wellington Council joined a number of local and regional government authorities in New Zealand in declaring a "Climate Emergency" (Davidson et al., 2020). The resultant Action Plan focuses on supporting locally-driven and locally-relevant adaptation plans, emphasizing a community-driven approach to plan adaptation responses (GWRC, 2020). Several current community-based adaptation planning initiatives are underway. For example, the Common 
Unity Project Aotearoa (CUPA) initiative in Te Awa Kairangi/ Lower Hutt encourages participation from those who have not traditionally been included in decision-making processes and also focuses on broader community development and wellbeing initiatives (Simon et al., 2020).

Another example are the community-led adaptation plans developed for Makara Beach in the Greater Wellington region. Over a 6-month period, community representatives worked together with local council, guided by technical experts, to develop adaptation pathway plans. Whilst reportedly considering a range of adaptation options (including managed retreat and defense structures), the plans adopt a business-asusual approach, advocating for sediment deposition in the shortmedium term, followed by seawalls to address longer-term impacts. Thus, despite a policy focus and strong advocacy for managed retreat in the longer term, very few examples of managed retreat have been successfully implemented in New Zealand (Hayward, 2008). Furthermore, studies into community preferences have found a significant preference for seawalls or large rocks and almost no appetite for managed retreat.

At the countrywide scale, in a report on adaptation action across sectors, the National Adaptation Technical Working Group identified some examples of proactive adaptation action. Those identified occurred in circumstances of high exposure and large inaction costs, and typically involved investment in flood risk and coastal hazard management, and some transport and food-security projects (Bond and Barth, 2020; Cradock-Henry et al., 2020; Paulik et al., 2020).

Overall, there is little evidence in Wellington and other New Zealand coastal cities of proactive or transformational action to reduce climate risk, similar to elsewhere (Hinkel et al., 2018). In most cases, action has been reactive and part of a sector's usual (path-dependent) natural hazard management response after extreme events occur, rather than being proactive and undertaken with a long-term transformational perspective. The adoption of hard defense options to respond to sea-level rise in the near term also constricts the ability to transition towards a flexible adaptation pathways approach. In addition, attempts to implement spatially sensitive setback lines based on risk, together with signals in some areas that retreat could be inevitable (following a pathways approach), have led to opposition and retraction (Manning et al., 2015). Yet the enactment of managed retreat in the aftermath of the Christchurch earthquakes provides an example to draw on for future climate-forced retreat from vulnerable coasts in New Zealand (Hoang and Noy, 2020; Nguyen, 2020).

Future adaptation of Wellington is constrained primarily by its geography. The natural landscape not only predisposes Wellington to a number of extreme hazards (such as earthquakes, storms and floods) but it limits accommodation and other possible response options through the comparative lack of flat (developable) land. While the decentralized approach to adaptation planning in New Zealand provides opportunities for innovation that are place-based and cognizant of the local context, there is concurrently a reliance on constrained local government resources for implementation. Limited budgets together with limited public engagement with climate-change adaptation has resulted in this being a low priority for some local governments in New Zealand (Archie et al., 2018).

\section{Sydney, Australia}

Sydney is the most populous city in Australia with over five million inhabitants, widely recognized for the iconic Sydney Harbor (Davies and Wright, 2014). Sydney was first inhabited by Aboriginal Australians over 20,000 years ago and then occupied by European settlers in the late 18th century. Over the past two centuries, large areas of mangrove and saltmarsh have been cleared for commercial, residential and recreational purposes (Rogers et al., 2019). More recently, increasing land scarcity in the Sydney region due to population growth, topographic constraints, and the presence of surrounding national parks, has led to significant urban infill and redevelopment of coastal areas, such as the AU\$6b Barangaroo mixed-use residential development close to the centre of the CBD.

While in the past, the coast of Sydney was by default the most active interface between land dwellers and sea travelers, today its coast forms an integral part of the city's appeal; its beaches are a draw card for recreation and tourism. While the New South Wales State and Australian national governments play a role in managing the Sydney coastal zone, the majority of routine management activities rests with local governments. Fifteen coastal local governments collectively formed the Sydney Coastal Councils Group in 1989 as an advocacy and collaboration collective to further coastal management outcomes for the Sydney region although, after subsequent local government amalgamations and other factors, only nine members now remain.

The coast of Sydney is subject to a range of hazards that are projected to intensify with climate change, in particular sea-level rise and associated tidal inundation, storm surge, flooding, and coastal erosion (Hague et al., 2020). For example, vulnerability to flooding from minor coastal inundation has increased fivefold since 1914. The areas of greatest exposure to sea-level rise are found around the low-lying areas of Botany Bay as well as Sydney's northern beaches (Preston et al., 2008). Coastal erosion is a significant issue and as Bonyhady (2010), p 85) notes, "inappropriate subdivisions (have) ... resulted in many houses and some high rises being built not just on the dunes but on the beach", exposing them to coastal erosion risk. A recent example of extreme coastal erosion occurred in Collaroy on Sydney's northern beaches in 2016, causing extensive destruction to property (Mortlock et al., 2017).

Hard protection approaches have historically been adopted in response to flooding, inundation and erosion. In Sydney Harbor, seawalls armor more than $50 \%$ of the shoreline (Bulleri and Chapman, 2010). Local governments responsible for managing coastal areas and associated risks have been subject to pressure from erosion-impacted coastal residents to protect their homes through the installation of armoring structures (O'Donnell, 2016).

In 2008, the Sydney Coastal Councils Group identified the need for practice-relevant research to build capacity to understand and address climate vulnerability (Measham et al., 
2011). A three-phase project was implemented, involving an extensive mapping process to visualize relative vulnerability (Preston et al., 2008); systems analysis of vulnerability interdependencies and council responses (Smith et al., 2008b); and case studies focusing on key adaptation barriers (Smith et al., 2008a). As a result, participating local governments received Australian Government funding to develop local adaptation plans.

In 2018, the State Government adopted the Coastal Management Act 2016 which required that by 2021 all coastal local governments would have developed Coastal Management Plans (CMPs) as defined in the Act and supporting policies. The selection of management responses, whether hard protection or other, was to be defined by the CMP process, with the State Environmental Planning Policy specifying councils are to be "reasonably satisfied" with the outcomes of their adaptation choices. This includes, for example, the potential for adverse impacts of protection structures on adjoining sections of coast.

The Greater Sydney Harbor region is currently undertaking a CMP and, at the time of writing, had completed the scoping study, which identified jurisdictional ambiguity as a major challenge to coastal management (Donaldson et al., 2018): a good example of the difficulties that bounded jurisdictions of any size have coping with transboundary issues like climate change (Barnes, 2017; Booth et al., 2020). Furthermore, it was noted that action along the coastal and estuarine margins was occurring in a localized manner through individual plans and initiatives, with limited integration (Donaldson et al., 2018). By establishing a Steering Committee and Partners Group, the CMP seeks to promote a whole-of-government partnership and a collaborative governance framework for managing Sydney Harbor.

The key incentive for such collaboration appears to be costsharing more so than integrated coastal planning. Other Sydney coastal councils (such as the Northern Beaches Council) will also embark on the development of CMPs as part of the updated legislative requirements. These plans will set the basis for adaptation planning over the coming years. Whether they promote a transition from the dominant hard protection approach to managing coastal risk or towards "risk-weighted decision pathways", as advocated by Preston et al. (2013), in which different portfolios of adaptation options are planned and implemented over time depending on the perceived risk, is yet to be seen.

Smith et al. (2008a) identified the following local government adaptive capacity constraints in reference to coastal management of Sydney:

- Local community conditions/characteristics: variable human capital; diverse perceptions; a disconnection between attitudes and behavior; and limited community education;

- The nature of existing infrastructure: aging infrastructure; existing non-climate related vulnerabilities; lack of council control over infrastructure; community expectations regarding infrastructure; and
- Planning and decision-making processes: jurisdictional overlaps; planning inconsistencies; political pressure; resources for planning; and legacies and trade-offs.

In 2015, despite controversy and challenges by many local authorities, the State Government undertook a process of council amalgamations in an effort to deliver efficiencies by scale. While amalgamation has delivered some adaptation benefits through economies of scale and cross-subsidization of adaptation initiatives, it may also lead to a disconnect between local decision-making and a depletion of local ownership over adaptation efforts as a result.

Capacity is not uniform across Sydney's local government areas. In a review of their adaptive capacity to respond to coastal impacts, the well-resourced coastal local governments in central Sydney were found to have the highest capacity to cope with their exposure and sensitivity to coastal hazards (Preston et al., 2008). Capacity was notably less developed in other areas of Sydney. For example, the local governments surrounding Botany Bay generally had lower levels of adaptive capacity, suggesting management of coastal hazards in these areas may be a greater challenge. In addition to local collaborations, some local governments have also connected globally. For example, the City of Sydney joined the C40 global network and 100 Resilient Cities program.

Local governments also face a dilemma in that there is guidance issued by the New South Wales State Government regarding projected coastal hazards (e.g. the Draft Sea Level Rise Policy Statement released in 2009), which potentially makes them responsible for development approval decisions yet unsupported financially to defend any development rejection decision brought by a developer in the Land and Environment Court (Sheehan et al., 2018). This is an example of an increasingly common situation in which local actors are becoming more aware of their legal exposure in climate-change decision-making yet are forced to act within a broader (State or National/Federal) context that often militates against effective local action (Kennedy et al., 2010; Cseh, 2019).

\section{PATH DEPENDENCY AND ADAPTATION: LOOKING TO THE FUTURE}

The five case studies discussed above demonstrate the nature of path dependency in various contexts. Table 1 summarizes the diversity of situations and the overriding importance of path dependency to explain recent and planned future actions to combat the effects of climate change.

One common observation is that despite advocacy for transformative adaptation responses, such as managed retreat, within some of the case study cities (e.g. Sydney and Wellington) and within the research community more broadly, the futures for all five cities favor protection, which is the most common recent (past) approach. For example, Hinkel et al. (2018) argue that the majority of coastal cities globally are developing along trajectories that will not allow sustainable adaptation to expected future sealevel rise. Some recent studies suggest sea level may be $1.65 \mathrm{~m}$ 
TABLE 1 | Comparison of case studies.

\begin{tabular}{|c|c|c|c|c|c|}
\hline & Shanghai & Metro Manila & Nadi & Wellington & Sydney \\
\hline Coastal hazards & $\begin{array}{l}\text { Storm surge, flooding, } \\
\text { sea-level rise } \\
\text { (amplified by } \\
\text { subsidence) }\end{array}$ & $\begin{array}{l}\text { Flooding, sea-level rise } \\
\text { (amplified by subsidence), } \\
\text { typhoons }\end{array}$ & $\begin{array}{l}\text { Sea-level rise (amplified by } \\
\text { subsidence), flooding }\end{array}$ & Tsunami, sea-level rise & Erosion, sea-level rise \\
\hline $\begin{array}{l}\text { Primary } \\
\text { adaptation driver }\end{array}$ & Extreme events & $\begin{array}{l}\text { Extreme events (capacity- } \\
\text { linked default) }\end{array}$ & Extreme events & $\begin{array}{l}\text { Extreme events (statutory } \\
\text { requirements) }\end{array}$ & $\begin{array}{l}\text { Extreme events (risk to } \\
\text { private property) }\end{array}$ \\
\hline $\begin{array}{l}\text { Dominant } \\
\text { Adaptation } \\
\text { Approach (Past) }\end{array}$ & Protect & Protect & $\begin{array}{l}\text { Protect and } \\
\text { accommodate }\end{array}$ & Protect & Protect and accommodate \\
\hline $\begin{array}{l}\text { Proposed } \\
\text { Adaptation } \\
\text { Approach (Future) }\end{array}$ & $\begin{array}{l}\text { Protect and } \\
\text { accommodate }\end{array}$ & $\begin{array}{l}\text { Protect, accommodate and } \\
\text { retreat }\end{array}$ & $\begin{array}{l}\text { Protect and } \\
\text { accommodate }\end{array}$ & $\begin{array}{l}\text { Community-led adaptation } \\
\text { planning; however, focus } \\
\text { remains on protection in the } \\
\text { long-term despite advocacy } \\
\text { for flexible adaptation } \\
\text { pathways }\end{array}$ & Protect and accommodate \\
\hline $\begin{array}{l}\text { Capacity } \\
\text { Constraints }\end{array}$ & $\begin{array}{l}\text { Limited bottom-up or } \\
\text { autonomous } \\
\text { adaptation }\end{array}$ & $\begin{array}{l}\text { Financial resources and } \\
\text { awareness, competing } \\
\text { priorities (like water), } \\
\text { geographical constraints }\end{array}$ & $\begin{array}{l}\text { Financial and awareness } \\
\text { constraints; (perceived) } \\
\text { dependence on donor } \\
\text { funding }\end{array}$ & Geographically constrained & $\begin{array}{l}\text { Variable capacity across } \\
\text { local governments; reduced } \\
\text { subsidiarity due to local } \\
\text { government } \\
\text { amalgamations }\end{array}$ \\
\hline $\begin{array}{l}\text { Capacity } \\
\text { Resources }\end{array}$ & $\begin{array}{l}\text { Top-down authority in } \\
\text { decision-making; } \\
\text { financial resources }\end{array}$ & $\begin{array}{l}\text { Growing bottom-up awareness } \\
\text { and autonomous adaptation; } \\
\text { non-government activities }\end{array}$ & $\begin{array}{l}\text { Growing awareness of } \\
\text { need for transformational } \\
\text { adaptation; generosity of } \\
\text { donors }\end{array}$ & $\begin{array}{l}\text { Decentralised and } \\
\text { participatory approach to } \\
\text { adaptation planning }\end{array}$ & $\begin{array}{l}\text { Economies of scale due to } \\
\text { amalgamation }\end{array}$ \\
\hline $\begin{array}{l}\text { Path } \\
\text { Dependencies }\end{array}$ & $\begin{array}{l}\text { History of engineering } \\
\text { protection and } \\
\text { continuing } \\
\text { technocentric } \\
\text { worldview }\end{array}$ & $\begin{array}{l}\text { History of (largely reactive) } \\
\text { protection; preferential focus } \\
\text { on economic growth and } \\
\text { accommodating growing } \\
\text { population }\end{array}$ & $\begin{array}{l}\text { History of } \\
\text { accommodation, low } \\
\text { awareness of long-term } \\
\text { nature of change }\end{array}$ & $\begin{array}{l}\text { Constrained topography and } \\
\text { history of successive } \\
\text { engineering protection works }\end{array}$ & $\begin{array}{l}\text { Private property rights and } \\
\text { history of successive } \\
\text { engineering protection } \\
\text { works }\end{array}$ \\
\hline
\end{tabular}

(above the 1986-2005 baseline) by 2100 (Horton et al., 2020), a figure that may well be higher in most (if not all) of our case-study cities because of land subsidence, both natural and humaninduced. If this projection were not sufficiently persuasive, then the consensus that sea level will continue rising beyond 2100 , perhaps reaching over $5 \mathrm{~m}$ above today's level by the year 2300 (Horton et al., 2020), points to a future for most of these coastal cities that is not consistent with their current development trajectories.

Factoring into this, especially in poorer contexts (like Nadi and Manila), is the lack of sufficient funds to enable transformational rather than incremental adaptation. It is clearly much easier for local (and national) governments to fund the construction or repair of sea defenses than it is for them to relocate vulnerable communities, although clearly the point will be reached-as it has with Jakarta (Indonesia)-where wholesale relocation is acknowledged as unavoidable and plans are drawn up to enable this (Shimamura and Mizunoya, 2020; Van de Vuurst and Escobar, 2020).

It is clearly most difficult to drive transformative adaptation of this kind in democracies, especially those in which key decisionmakers are elected every few years and there are grassroots movements that either deny or actively resist the need for such adaptation, as in Sydney and Wellington. While megaengineering projects are obviously funded and undertaken in countries like Australia and New Zealand, they are in the name of "progress" and "economic growth" rather than anything like "adaptation" that might be perceived negatively by the electorate. In contrast, in situations like Manila and Shanghai, national top-down decision-making in the recent past has been enduring, effective and often transformative; examples from the Philippines include New Clark City, which will accommodate 1.2 million people from largely vulnerable coastal areas, and in China the Three Gorges Dam and South-North Water Transfer Project (Ran et al., 2020; Rogers et al., 2020). Then in countries like the Fiji Islands, where there are recent trends of growing dependency on external (donor) funding for adaptation, it is likely that over the next 2 decades, adaptation in coastal cities like Nadi will be largely reactive, unplanned and autonomous, as donor funds are redirected towards their domestic adaptation (Nunn and Kumar, 2019).

Urban settlements are comparatively recent developments, megacities essentially a late 20th century phenomenon, so the nature of planning therein has no great experiential legacy. In fact, urban settlements were created so that particular groups of people might advantage themselves; the linking of economic growth to both population and spatial growth was once the principal reasons for cities to exist (Berry, 2007). In many instances, the dangers of agendas of growth being foregrounded to the exclusion of those of sustainability have been clearly shown; one example is that of the Japanese city of Kobe, the unsustainably rapid growth of which was abruptly halted by the 1995 earthquake, its human and economic effects amplified by the lack of planned development and high population densities (Matsuyama et al., 2015). While there are numerous examples of repeated failures within urban settlements 
in relation to risk management, there continues to be little emphasis on adaptive management, and more specifically learning (Smith and Smith, 2006), to inform decisions through a cycle of continuous and informed improvement. For example, Jacobson et al. (2014) in a survey of Australian coastal managers, found that fewer than half of respondents (42\%) used monitoring and evaluation to inform adaptive management, and less than one third (32\%) for assessing management effectiveness.

The dominance of "protect" approaches to adaptation in coastal cities is an expression of their inhabitants' desire to maintain their city's original purpose: that of growing prosperity. This might explain the reluctance of such cities to embrace "retreat" and other transformational solutions for these imply a failure of function. They involve an admission of error: what was once promised is no longer achievable. And while such admissions are likely to become widespread over the next few decades, in particular as humanity slowly realizes it has no choice but to adapt transformatively to future long-term climate-driven stressors, they are currently hindering optimal responses to current stressors (Ribeiro and Goncalves, 2019; Matyas, 2020).

\section{CONCLUSION}

It is clear that path dependency is a powerful influence on recent and planned (future) adaptation to climate change (and other livelihood stressors) in coastal cities across the Asia-Pacific region. Our analysis suggests that while almost every coastal city (including all five case studies) in this region is handicapped in their planning by their historical favoring of "protect" responses, it is those cities where decision-makers are regularly elected (rather than appointed) that may be slowest to embrace more transformative responses because of popular resistance to the disruptive effects of these. Yet this may be due to neoliberal market pressures, entrenched and perverse institutional arrangements, and the influence of elites, rather than democratic processes per se.

\section{REFERENCES}

Abon, C. C., David, C. P. C., and Pellejera, N. E. B. (2011). Reconstructing the Tropical Storm Ketsana Flood Event in Marikina River, Philippines. Hydrol. Earth Syst. Sci. 15, 1283-1289. doi:10.5194/hess-15-1283-2011

Archie, K. M., Chapman, R., and Flood, S. (2018). Climate Change Response in New Zealand Communities: Local Scale Adaptation and Mitigation Planning. Environ. Dev. 28, 19-31. doi:10.1016/j.envdev.2018.09.003

Arden, S., and Jawitz, J. W. (2019). The Evolution of Urban Water Systems: Societal Needs, Institutional Complexities, and Resource Costs. Urban Water J. 16, 92-102. doi:10.1080/1573062x.2019.1634109

Attané, I., and Barbieri, M. (2009). La démographie de l'Asie de l'Est et du Sud-Est des années 1950 aux années 2000. Population 64, 7-154. doi:10.3917/popu.901.0007

Bankoff, G. (2003). Cultures of Disaster: Society and Natural Hazard in the Philippines. London: Routledge.

Bao, J., Gao, S., and Ge, J. (2020). Coastal Engineering Evolution in Low-Lying Areas and Adaptation Practice since the Eleventh century, Jiangsu Province, China. Climatic Change 162, 799-817. doi:10.1007/s10584-020-02738-x

Barnes, J. (2017). The Future of the Nile: Climate Change, Land Use, Infrastructure Management, and Treaty Negotiations in a Transboundary
For the future, it must be hoped that a growing awareness of both the severity and immediacy of climate change, as well as the likelihood of irreversible multi-century future sea-level rise, will inform not simply the agendas of key government decisionmakers but also the minds of all urban dwellers so that transformative adaptation-like the trailblazing relocation of Jakarta-will become more widely adopted.

Yet at the same time, it seems clear that most large coastal cities in the Asia-Pacific region would be experiencing challenges around sustainability even were the climate not changing and aggravating these challenges. Adaptation to climate change may not therefore go hand in hand with the attainment of sustainability of cities in this region or elsewhere, requiring that current and recent trends of urban development in coastal locations be examined holistically to identify interventions that will sustain future urban functionality and livelihoods, even perhaps divorced from place.

\section{DATA AVAILABILITY STATEMENT}

The original contributions presented in the study are included in the article/supplementary material, further inquiries can be directed to the corresponding author.

\section{AUTHOR CONTRIBUTIONS}

PN and TS conceived the paper and contributed most parts. CE-B contributed three case studies and to the entire article.

\section{FUNDING}

This research was supported by the Australian Government through the Australian Research Council's Discovery Projects Funding Scheme (Project FT180100652).

River basin. Wiley Interdiscip. Reviews-Climate Change 8, e449. doi:10.1002/ wcc. 449

Barnett, J., and O’Neill, S. (2010). Maladaptation. Glob. Environ. Change 20, 211-213. doi:10.1016/j.gloenvcha.2009.11.004

Bernard, K., and Cook, S. (2015). Luxury Tourism Investment and Flood Risk: Case Study on Unsustainable Development in Denarau Island Resort in Fiji. Int. J. Disaster Risk Reduction 14, 302-311. doi:10.1016/j.ijdrr.2014.09.002

Berry, B. J. L. (2007). The World's First Cities. Texas, Lulu: McKinney.

Bond, S., and Barth, J. (2020). Care-full and Just: Making a Difference through Climate Change Adaptation. Cities 102, 102734. doi:10.1016/ j.cities.2020.102734

Bonyhady, T. (2010). "Swimming in the Streets: the Beginnings of Planning for Sea Level Rise," in Adaptation to Climate Change: Law and Policy. Editors T. BONYHADY, A. MACINTOSH, and J. MCDONALD (Sydney: Federation Press).

Booth, L., Fleming, K., Abad, J., Schueller, L. A., Leone, M., Scolobig, A., et al. (2020). Simulating Synergies between Climate Change Adaptation and Disaster Risk Reduction Stakeholders to Improve Management of Transboundary Disasters in Europe. Int. J. Disaster Risk Reduct 49, 101668. doi:10.1016/j.ijdrr.2020.101668

Bulleri, F., and Chapman, M. G. (2010). The Introduction of Coastal Infrastructure as a Driver of Change in marine Environments. J. Appl. Ecol. 47, 26-35. doi:10.1111/j.1365-2664.2009.01751.x 
Burger, J., Brown, J., Day, J., Flanagan, T., and Roy, E. (2018). The Central Role of Energy in the Urban Transition: Global Challenges for Sustainability. Biophysical Econ. Resource Qual. 4, 1-13. doi:10.1007/s41247-019-0053-z

Cagigal, L., Rueda, A., Castanedo, S., Cid, A., Perez, J., Stephens, S. A., et al. (2020). Historical and Future Storm Surge Around New Zealand: From the 19th century to the End of the 21st century. Int. J. Climatol 40, 1512-1525. doi:10.1002/joc.6283

Carey, J. (2020). Core Concept: Managed Retreat Increasingly Seen as Necessary in Response to Climate Change's Fury. Proc. Natl. Acad. Sci. USA 117, 13182-13185. doi:10.1073/pnas.2008198117

Chan, F. K. S., Mitchell, G., Adekola, O., and Mcdonald, A. (2012). Flood Risk in Asia's Urban Mega-Deltas. Environ. Urbanization Asia 3, 41-61. doi:10.1177/ 097542531200300103

Chandra, A., and Gaganis, P. (2016). Deconstructing Vulnerability and Adaptation in a Coastal River basin Ecosystem: a Participatory Analysis of Flood Risk in Nadi, Fiji Islands. Clim. Dev. 8, 256-269. doi:10.1080/17565529.2015.1016884

Chen, M., Liu, W., and Tao, X. (2013). Evolution and Assessment on China's Urbanization 1960-2010: Under-urbanization or Over-urbanization? Habitat Int. 38, 25-33. doi:10.1016/j.habitatint.2012.09.007

Cheng, H.-Q., and Chen, J.-Y. (2017). Adapting Cities to Sea Level Rise: A Perspective from Chinese Deltas. Adv. Clim. Change Res. 8, 130-136. doi:10.1016/j.accre.2017.05.006

Cradock-Henry, N. A., Blackett, P., Hall, M., Johnstone, P., Teixeira, E., and Wreford, A. (2020). Climate Adaptation Pathways for Agriculture: Insights from a Participatory Process. Environ. Sci. Pol. 107, 66-79. doi:10.1016/ j.envsci.2020.02.020

Cseh, A. (2019). Aligning Climate Action with the Self-Interest and Short-Term Dominated Priorities of Decision-Makers. Clim. Pol. 19, 139-146. doi:10.1080/ 14693062.2018.1478791

Davidson, K., Briggs, J., Nolan, E., Bush, J., Hakansson, I., and Moloney, S. (2020). The Making of a Climate Emergency Response: Examining the Attributes of Climate Emergency Plans. Urban Clim. 33, 100666. doi:10.1016/ j.uclim.2020.100666

Davies, P. J., and Wright, I. A. (2014). A Review of Policy, Legal, Land Use and Social Change in the Management of Urban Water Resources in Sydney, Australia: A Brief Reflection of Challenges and Lessons from the Last 200 Years. Land Use Policy 36, 450-460. doi:10.1016/j.landusepol.2013.09.009

Day, J. W., Gunn, J. D., Folan, W. J., Yáñez-Arancibia, A., and Horton, B. P. (2007). Emergence of Complex Societies after Sea Level Stabilized. Eos Trans. AGU 88, 169-170. doi:10.1029/2007eo150001

Day, J. W., Gunn, J. D., Folan, W. J., Yáñez-Arancibia, A., and Horton, B. P. (2012). The Influence of Enhanced post-glacial Coastal Margin Productivity on the Emergence of Complex Societies. The J. Isl. Coastal Archaeol. 7, 23-52. doi:10.1080/15564894.2011.650346

Day, J. W., D’Elia, C. F., Wiegman, A. R. H., Rutherford, J. S., Hall, C. A. S., Lane, R. R., et al. (2018). The Energy Pillars of Society: Perverse Interactions of Human Resource Use, the Economy, and Environmental Degradation. Biophys. Econ. Resour. Qual. 3, 2. doi:10.1007/s41247-018-0035-6

de Leon, E. G., and Pittock, J. (2017). Integrating Climate Change Adaptation and Climate-Related Disaster Risk-Reduction Policy in Developing Countries: A Case Study in the Philippines. Clim. Dev. 9, 471-478. doi:10.1080/ 17565529.2016.1174659

Doberstein, B., Tadgell, A., and Rutledge, A. (2020). Managed Retreat for Climate Change Adaptation in Coastal Megacities: A Comparison of Policy and Practice in Manila and Vancouver. J. Environ. Manage. 253, 109753. doi:10.1016/ j.jenvman.2019.109753

Donaldson, P., Rissik, D., Vos, C., Downes, A., and Gough, M. (2018). Greater Sydney Harbour Coastal Management Plan, Scoping Study: Final Report. Sydney: NSW Government.

Ebrey, P., and Walthall, A. (2014). East Asia: A Cultural, Social and Political History. Boston: Wadsworth.

Fair, H. (2018). Three Stories of Noah: Navigating Religious Climate Change Narratives in the Pacific Island Region. Geo-Geogr. Environ. 5, e00068. doi:10.1002/geo2.68

Feng, X. H., Xiu, C. L., Bai, L. M., Zhong, Y. X., and Wei, Y. (2020). Comprehensive Evaluation of Urban Resilience Based on the Perspective of Landscape Pattern: A Case Study of Shenyang City. Cities 104, 102722. doi:10.1016/ j.cities.2020.102722
Friedmann, J. (2011). Becoming Urban: Periurban Dynamics in Vietnam and China - Introduction. Pac. Aff. 84, 425-434. doi:10.5509/2011843425

Gallopín, G. C. (2020). Cities, Sustainability, and Complex Dissipative Systems. A Perspective 2. doi:10.3389/frsc.2020.523491

Georgeson, L., Maslin, M., Poessinouw, M., and Howard, S. (2016). Adaptation Responses to Climate Change Differ between Global Megacities. Nat. Clim Change 6, 584-588. doi:10.1038/nclimate2944

Güneralp, B., Reba, M., Hales, B. U., Wentz, E. A., and Seto, K. C. (2020). Trends in Urban Land Expansion, Density, and Land Transitions from 1970 to 2010: a Global Synthesis. Environ. Res. Lett. 15, 044015. doi:10.1088/1748-9326/ab6669

GWRC (2020). Greater Wellington Regional Council: Regional Climate Change Emergency Action Plan.

Haberkorn, G. (1992). Temporary Versus Permanent Population Mobility in Melanesia - A Case Study From Vanuatu. Sustain. Sci. 26 (3), 806-842. doi: $10.2307 / 2546966$

Hague, B., Mcgregor, S., Murphy, B. F., Reef, R., and Jones, D. A. (2020). Sea Level Rise Driving Increasingly Predictable Coastal Inundation in Sydney, Australia. Earths Future 8, e2020EF001607. doi:10.1029/2020ef001607

Hayward, B. (2008). 'Nowhere Far from the Sea': Political Challenges of Coastal Adaptation to Climate Change in New Zealand. Polit. Sci. 60, 47-59. doi:10.1177/003231870806000105

Hinkel, J., Aerts, J. C. J. H., Brown, S., Jiménez, J. A., Lincke, D., Nicholls, R. J., et al. (2018). The Ability of Societies to Adapt to Twenty-First-century Sea-Level Rise. Nat. Clim Change 8, 570-578. doi:10.1038/s41558-018-0176-z

Hoang, T., and Noy, I. (2020). Wellbeing after a Managed Retreat: Observations from a Large New Zealand Program. Int. J. Disaster Risk Reduction 48, 101589. doi:10.1016/j.ijdrr.2020.101589

Hohn, H.-W., and Schneider, V. (1991). Path-dependency and Critical Mass in the Development of Research and Technology: a Focused Comparison. Sci. Public Pol. 18, 111-122. doi:10.1093/spp/18.2.111

Horton, B. P., Khan, N. S., Cahill, N., Lee, J. S. H., Shaw, T. A., Garner, A. J., et al. (2020). Estimating Global Mean Sea-Level Rise and its Uncertainties by 2100 and 2300 from an Expert Survey. Npj Clim. Atmos. Sci. 3, 18. doi:10.1038/ s41612-020-0126-0

Inayatullah, S. (2008). Six Pillars: Futures Thinking for Transforming. Foresight 10, 4-21. doi:10.1108/14636680810855991

IPCC (2018). "Summary for Policymakers," in Global Warming of $1.5^{\circ} \mathrm{C}$. An IPCC Special Report on the Impacts of Global Warming of $1.5^{\circ} \mathrm{C}$ above Pre-industrial Levels and Related Global Greenhouse Gas Emission Pathwaysthe Context of Strengthening the Global Response to the Threat of Climate Change, Sustainable Development, and Efforts to Eradicate Poverty. Editors V. MASSONDELMOTTE, P. ZHAI, H.-O. PÖRTNER, D. ROBERTS, J. SKEA, P. R. SHUKLA, et al. (Geneva: World Meteorological Organization).

Jacobson, C., Carter, R. W., Thomsen, D. C., and Smith, T. F. (2014). Monitoring and Evaluation for Adaptive Coastal Management. Ocean Coastal Manage. 89, 51-57. doi:10.1016/j.ocecoaman.2013.12.008

Kates, R. W., Travis, W. R., and Wilbanks, T. J. (2012). Transformational Adaptation when Incremental Adaptations to Climate Change Are Insufficient. Proc. Natl. Acad. Sci. 109, 7156-7161. doi:10.1073/ pnas. 1115521109

Keen, M., and Connell, J. (2019). Regionalism and Resilience? Meeting Urban Challenges in Pacific Island States. Urban Pol. Res. 37, 324-337. doi:10.1080/ 08111146.2019 .1626710

Kempf, W. (2017). "Climate Change, Christian Religion and Songs: Revisiting the Noah story in the central Pacific," in Environmental Transformation and Cultural Responses. Editors E. DÜRR and A. PASCHT (New York: Palgrave Macmillan). doi:10.1057/978-1-137-53349-4_2

Kennedy, D., Stocker, L., and Burke, G. (2010). Australian Local Government Action on Climate Change Adaptation: Some Critical Reflections to Assist Decision-Making. Local Environ. 15, 805-816. doi:10.1080/ 13549839.2010.514602

Klöck, C., and Nunn, P. D. (2019). Adaptation to Climate Change in Small Island Developing States: a Systematic Literature Review of Academic Research. J. Environ. Dev. 28, 196-218. doi:10.1177/1070496519835895

Korovulavula, I., Nunn, P. D., Kumar, R., and Fong, T. (2019). Peripherality as Key to Understanding Opportunities and Needs for Effective and Sustainable Climate-Change Adaptation: a Case Study from Viti Levu Island, Fiji. Clim. Dev. 12, 888-898. doi:10.1080/17565529.2019.1701972 
Kundu, D., Mueller, A., Schmidt-Seiwert, V., Binot, R., Kiel, L., and Pandey, A. (2020). Spatial Structures and Trends of Cities in Europe and Asia: A Joint Methodological Approach Based on the Global Human Settlement Layer. Environ. Urbanization Asia 11, 195-217. doi:10.1177/0975425320958850

Kurashimo, E., Henrys, S., Sato, H., Iwasaki, T., Okaya, D., Sutherland, R., et al. (2015). SAHKE Seismic-Scatter Imaging of Subduction beneath Wellington, North Island, New Zealand. Geophys. Res. Lett. 42, 3240-3247. doi:10.1002/2015gl063230

Lawler, A. (2014). Sailing Sinbad's Seas. Science 344, 1440-1445. doi:10.1126/ science.344.6191.1440

Lawrence, J., Bell, R., and Stroombergen, A. (2019). A Hybrid Process to Address Uncertainty and Changing Climate Risk in Coastal Areas Using Dynamic Adaptive Pathways Planning, Multi-Criteria Decision Analysis \& Real Options Analysis: A New Zealand Application. Sustainability 11, 406. doi:10.3390/sul1020406

Laycock, K. E., and Mitchell, C. L. (2019). Social Capital and Incremental Transformative Change: Responding to Climate Change Experts in Metro Manila. Climatic Change 152, 47-66. doi:10.1007/s10584-018-2360-6

Lee, H., Son, J., Joo, D., Ha, J., Yun, S., Lim, C. H., et al. (2020). Sustainable Water Security Based on the SDG Framework: A Case Study of the 2019 Metro Manila Water Crisis. Sustainability 12, 6860. doi:10.3390/su12176860

Lee, J. W. (2019). Lagged Effect of Exports, Industrialization and Urbanization on Carbon Footprint in Southeast Asia. Int. J. Sustainable Dev. World Ecol. 26, 398-405. doi:10.1080/13504509.2019.1605425

Liu, Y., Sun, Q., Thomas, I., Zhang, L., Finlayson, B., Zhang, W., et al. (2015). Middle Holocene Coastal Environment and the Rise of the Liangzhu City Complex on the Yangtze delta, China. Quat. Res. 84, 326-334. doi:10.1016/j.yqres.2015.10.001

Malekandathil, P. (2013). Maritime India: Trade, Religion and Polity in the Indian Ocean. Delhi: Primus Books.

Manning, M., Lawrence, J., King, D. N., and Chapman, R. (2015). Dealing with Changing Risks: a New Zealand Perspective on Climate Change Adaptation. Reg. Environ. Change 15, 581-594. doi:10.1007/s10113-014-0673-1

Matsuyama, M., Kimura, R., Kimura, R., and Hayashi, H. (2015). Organizational Structure and Institutions for Disaster Prevention: Research on the 1995 Great Hanshin-Awaji Earthquake in Kobe City. J. Disaster Res. 10, 1051-1066. doi:10.20965/jdr.2015.p1051

Matyas, D. (2020). Towards a Legal Toolkit for Disaster Resilience and Transformation. Disasters. 45, 453-476.

Mcleod, E., Hinkel, J., Vafeidis, A. T., Nicholls, R. J., Harvey, N., and Salm, R. (2010). Sea-level Rise Vulnerability in the Countries of the Coral Triangle. Sustain. Sci. 5, 207-222. doi:10.1007/s11625-010-0105-1

McNamara, K. E. (2013). A State of Emergency: How Local Businesses Experienced the 2012 Flood in Fiji. Aust. J. Emerg. Manage. 28, 17-23.

Measham, T. G., Preston, B. L., Smith, T. F., Brooke, C., Gorddard, R., Withycombe, G., et al. (2011). Adapting to Climate Change through Local Municipal Planning: Barriers and Challenges. Mitig Adapt Strateg. Glob. Change 16, 889-909. doi:10.1007/s11027-011-9301-2

Meerow, S. (2017). Double Exposure, Infrastructure Planning, and Urban Climate Resilience in Coastal Megacities: A Case Study of Manila. Environ. Plan. A. 49, 2649-2672. doi:10.1177/0308518x17723630

Mercado, J. M. R., Kawamura, A., and Amaguchi, H. (2020). Interrelationships of the Barriers to Integrated Flood Risk Management Adaptation in Metro Manila, Philippines. Int. J. Disaster Risk Reduction 49, 101683. doi:10.1016/j.ijdrr.2020.101683

Mi, H., Wang, W., and Qiao, G. (2016). Shanghai Shoreline Evolution Interpreted from Historical Atlas and Remote Sensing Imagery over the Past 2,200 Years. Int. Arch. Photogramm. Remote Sens. Spat. Inf. Sci. XLI-B8 (41), 1157-1160. Commission VIII. doi:10.5194/isprsarchives-xli-b8-1157-2016

Min, S.-K., Zhang, X., Zwiers, F. W., and Hegerl, G. C. (2011). Human Contribution to More-Intense Precipitation Extremes. Nature 470, 378-381. doi:10.1038/nature09763

Mitchell, C. L., and Laycock, K. E. (2019). Planning for Adaptation to Climate Change: Exploring the Climate Science-to-Practice Disconnect. Clim. Dev. 11 (1), 60-68. doi:10.1080/17565529.2017.1411243

Mora, C., Dousset, B., Caldwell, I. R., Powell, F. E., Geronimo, R. C., Bielecki, C. R., et al. (2017). Global Risk of Deadly Heat. Nat. Clim Change 7, 501-506. doi: $10.1038 /$ nclimate 3322

Rivero Moreno, L. D. (2020). Sustainable City Storytelling: Cultural Heritage as a Resource for a Greener and Fairer Urban Development. Jchmsd 10, 399-412. doi:10.1108/jchmsd-05-2019-0043

Mortlock, T. R., Goodwin, I. D., Mcaneney, J. K., and Roche, K. (2017). The June 2016 Australian East Coast Low: Importance of Wave Direction for Coastal. Erosion Assess. Water 9, 121. doi:10.3390/w9020121
Nerem, R. S., and Fasullo, J. (2019). Observations of the Rate and Acceleration of Global Mean Sea Level Change. Bull. Am. Meteorol. Soc. 100, S15-S18. doi:10.1175/bams-d-18-0247.1

Nguyen, C. N. (2020). Homeowners' Choice when the Government Proposes a Managed Retreat. Int. J. Disaster Risk Reduction 47, 101543. doi:10.1016/ j.ijdrr.2020.101543

Nunn, P. D., and Campbell, J. R. (2020). Rediscovering the Past to Negotiate the Future: How Knowledge about Settlement History on High Tropical Pacific Islands Might Facilitate Future Relocations. Environ. Dev. 35, 100546. doi:10.1016/j.envdev.2020.100546

Nunn, P. D., and Kumar, R. (2019). Cashless Adaptation to Climate Change: Unwelcome yet Unavoidable? One Earth 1, 31-34. doi:10.1016/j.oneear.2019.08.004

Nunn, P. D., and Mcnamara, K. E. (2019). "Failing Adaptation in Island Contexts: the Growing Need for Transformational Change," in Dealing with Climate Change on Small Islands: Towards Effective and Sustainable Adaptation. Editors C. KLOCK and M. FINK (Gottingen: Gottingen University Press). doi:10.17875/gup2019-1210

Nunn, P. D., Mulgrew, K., Scott-Parker, B., Hine, D. W., Marks, A. D. G., Mahar, D., et al. (2016). Spirituality and Attitudes towards Nature in the Pacific Islands: Insights for Enabling Climate-Change Adaptation. Climatic Change 136, 477-493. doi:10.1007/s10584-016-1646-9

Nunn, P. D., Mclean, R. F., Dean, A., Fong, T., Iese, V., Katonivualiku, M., et al. (2020). "Adaptation to Climate Change: Contemporary Challenges and Perspectives," in Climate Change and Impacts in the Pacific. Editor L. KUMAR (Berlin: Springer). doi:10.1007/978-3-030-32878-8_14

Nunn, P. (2009). Responding to the Challenges of Climate Change in the Pacific Islands: Management and Technological Imperatives. Clim. Res. 40, 211-231. doi: $10.3354 / \mathrm{cr} 00806$

Nunn, P. D. (2013). The End of the Pacific? Effects of Sea Level Rise on Pacific Island Livelihoods. Singap J. Trop. Geogr. 34, 143-171. doi:10.1111/sjtg.12021

O'Donnell, T. (2016). Legal Geography and Coastal Climate Change Adaptation: the Vaughan Litigation. Geogr. Res. 54, 301-312. doi:10.1111/1745-5871.12170

Panwar, N. S., and Mishra, A. K. (2020). COVID-19 Crisis and Urbanization, Migration and Inclusive City Policies in India: A New Theoretical Framework. J. Public Aff. 20 (4), e2249. doi:10.1002/pa.2249

Paulik, R., Stephens, S. A., Bell, R. G., Wadhwa, S., and Popovich, B. (2020). National-Scale Built-Environment Exposure to 100-Year Extreme Sea Levels and Sea-Level Rise. Sustainability 12, 1513. doi:10.3390/su12041513

Power, S. B., Delage, F. P. D., Chung, C. T. Y., Ye, H., and Murphy, B. F. (2017). Humans Have Already Increased the Risk of Major Disruptions to Pacific Rainfall. Nat. Commun. 8, 14368. doi:10.1038/ncomms14368

Preston, B., Smith, T. F., Brooke, C., Measham, T., Withycombe, G., Beveridge, B., et al. (2008). Mapping Climate Change Vulnerability in the Sydney Coastal Councils Group, Prepared for the Sydney Coastal Councils Group. Sydney: CSIRO and Sydney Coastal Councils Group.

Preston, B. L., Maloney, M., Thomsen, D. C., Smith, T. F., Mangoyana, R., and Conlon, B. (2013). Multi-Criteria Analysis of Coastal Adaptation Options for Local Government. Prepared for the Sydney Coastal Councils Group. Oak Ridge, TN and Sippy Downs, QLD: Oak Ridge National Laboratory and University of the Sunshine Coast.

Qian, Z. (2015). From the First Five-Year Plan to the Cultural Revolution: the Prereform Urban Transformation of Hangzhou, China. Plann. Perspect. 30, 571-595. doi:10.1080/02665433.2014.995694

Ran, A. B., Fan, J. B., Zhou, L., and Zhang, C. G. (2020). Geo-Disaster Governance under the IAD Framework: The Case Study of Chongqing's Three Gorges Reservoir Region, China. Sustainability 12, 5517. doi:10.3390/su12145517

Reisinger, A., Kitching, R. L., Chiew, F., Hughes, L., Newton, P. C. D., Schuster, S. S., et al. (2014). "Australasia," in Climate Change 2014: Impacts, Adaptation, and Vulnerability. Part B: Regional Aspects. Contribution of Working Group II to the Fifth Assessment Report of the Intergovernmental Panel on Climate Change. Editors V. R. BARROS, C. B. FIELD, D. J. DOKKEN, M. D. MASTRANDREA, K. J. MACH, T. E. BILIR, et al. (Cambridge: Cambridge University Press).

Ren, Z.-Y., and Liu, H. (2015). Numerical Study of Potential Extreme Tsunami hazard in South China Sea. Proced. Eng. 126, 332-338. doi:10.1016/j.proeng.2015.11.201

Renfrew, C., and Liu, B. (2018). The Emergence of Complex Society in China: the Case of Liangzhu. Antiquity 92, 975-990. doi:10.15184/aqy.2018.60

Revi, A., Satterthwaite, D. E., Aragón-Durand, F., Corfee-Morlot, J., Kiunsi, R. B. R., Pelling, M., et al. (2014). "Urban Areas," in Climate Change 2014: Impacts, Adaptation, and Vulnerability: Part A: Global and Sectoral Impacts. 
Contribution of Working Group II to the Fifth Assessment Report of the Intergovernmental Panel on Climate Change. Editors C. B. FIELD, V. R. BARROS, D. J. DOKKEN, K. J. MACH, M. D. MASTRANDREA, T. E. BILIR, et al. (Cambridge: Cambridge University Press).

Ribeiro, P. J. G., and Pena Jardim Gonçalves, L. A. (2019). Urban Resilience: A Conceptual Framework. Sustainable Cities Soc. 50, 101625. doi:10.1016/ j.scs.2019.101625

Robinne, F.-N., Bladon, K. D., Miller, C., Parisien, M.-A., Mathieu, J., and Flannigan, M. D. (2018). A Spatial Evaluation of Global Wildfire-Water Risks to Human and Natural Systems. Sci. Total Environ. 610-611, 1193-1206. doi:10.1016/j.scitotenv.2017.08.112

Rodolfo, K. S., and Siringan, F. P. (2006). Global Sea-Level Rise Is Recognised, but Flooding from Anthropogenic Land Subsidence Is Ignored Around Northern Manila Bay, Philippines. Disasters 30, 118-139. doi:10.1111/j.1467-9523.2006.00310.x

Rogers, K., Mogensen, L. A., Davies, P., Kelleway, J., Saintilan, N., and Withycombe, G. (2019). Impacts and Adaptation Options for Estuarine Vegetation in a Large City. Landscape Urban Plann. 182, 1-11. doi:10.1016/ j.landurbplan.2018.09.022

Rogers, S., Chen, D., Jiang, H., Rutherfurd, I., Wang, M., Webber, M., et al. (2020). An Integrated Assessment of China's South-North Water Transfer Project. Geogr. Res. 58, 49-63. doi:10.1111/1745-5871.12361

Runhaar, H., Mees, H., Wardekker, A., van der Sluijs, J., and Driessen, P. P. J. (2012). Adaptation to Climate Change-Related Risks in Dutch Urban Areas: Stimuli and Barriers. Reg. Environ. Change 12 (4), 777-790. doi:10.1007/s10113-012-0292-7

Sadr, S. M. K., Casal-Campos, A., Fu, G., Farmani, R., Ward, S., and Butler, D. (2020). Strategic Planning of the Integrated Urban Wastewater System Using Adaptation Pathways. Water Res. 182, 116013. doi:10.1016/j.watres.2020.116013

Shimamura, T., and Mizunoya, T. (2020). Sustainability Prediction Model for Capital City Relocation in Indonesia Based on Inclusive Wealth and System Dynamics. Sustainability 12, 4336. doi:10.3390/su12104336

Shove, E. (2010). Beyond the ABC: Climate Change Policy and Theories of Social Change. Environ. Plan. A. 42, 1273-1285. doi:10.1068/a42282

Simon, K., Diprose, G., and Thomas, A. C. (2020). Community-led Initiatives for Climate Adaptation and Mitigation. Kōtuitui: New Zealand J. Soc. Sci. Online 15, 93-105. doi:10.1080/1177083x.2019.1652659

Slaev, A. D., Nedović-Budić, Z., Krunić, N., Petrić, J., and Daskalova, D. (2018). Suburbanization and Sprawl in post-socialist Belgrade and Sofia. Eur. Plann. Stud. 26, 1389-1412. doi:10.1080/09654313.2018.1465530

Smith, T. F., and Smith, D. C. (2006). "Institutionalising Adaptive Learning for Coastal Management," in Coastal Management in Australia: Key Institutional and Governance Issues for Coastal Natural Resource Management and Planning. Editors N. LAZAROW, R. SOUTER, R. FEARON, and S. DOVERS (Brisbane: CRC for Coastal Zone, Estuary and Wateray Management).

Smith, T. F., Brooke, B., Measham, T., Preston, B., Gorddard, R., Withycombe, G., et al. (2008a). Case Studies of Adaptive Capacity: Systems Approach to Regional Climate Change Adaptation Strategies. Sydney: Sydney Coastal Councils Group.

Smith, T. F., Preston, B., Gorddard, R., Brooke, C., Measham, T., Withycombe, G., et al. (2008b). Regional Workshops Synthesis Report: Sydney Coastal Councils' Vulnerability to Climate Change: Part 1. Sydney: CSIRO and Sydney Coastal Councils Group.

Smith, T., Thomsen, D., Gould, S., Schmitt, K., and Schlegel, B. (2013). Cumulative Pressures on Sustainable Livelihoods: Coastal Adaptation in the Mekong Delta. Sustainability 5, 228-241. doi:10.3390/su5010228

Stern, N. (2006). The Stern Review on the Economic Effects of Climate Change (Report to the British Government). London: HM Treasury of the UK Government. HM Treasury-Retrieved from:.

Tadgell, A., Mortsch, L., and Doberstein, B. (2017). Assessing the Feasibility of Resettlement as a Climate Change Adaptation Strategy for Informal Settlements in Metro Manila, Philippines. Int. J. Disaster Risk Reduction 22, 447-457. doi:10.1016/j.ijdrr.2017.01.005

Tessler, Z. D., Vorosmarty, C. J., Grossberg, M., Gladkova, I., Aizenman, H., Syvitski, J. P. M., et al. (2015). Profiling Risk and Sustainability in Coastal Deltas of the World. Science 349, 638-643. doi:10.1126/science.aab3574

Thomsen, D. C., Smith, T. F., and Keys, N. (2012). Adaptation or Manipulation? Unpacking Climate Change Response Strategies. Ecol. Soc. 17, 3. doi:10.5751/ es-04953-170320

Tong, M., Hansen, A., Hanson-Easey, S., Cameron, S., Xiang, J., Liu, Q., et al. (2015). Infectious Diseases, Urbanization and Climate Change: Challenges in Future China. Ijerph 12, 11025-11036. doi:10.3390/ijerph120911025
UN (2019). World Population Prospects 2019: Highlights. New York: UN Department of Economic and Social Affairs, Population Division.

UNDRR (2019). Disaster Risk Reduction in the Philippines: Status Report 2019. Bangkok: UNDRR Regional Office for Asia and the Pacific.

Valenzuela, V. P. B., Esteban, M., and Onuki, M. (2020). Perception of Disasters and Land Reclamation in an Informal Settlement on Reclaimed Land: Case of the BASECO Compound, Manila, the Philippines. Int. J. Disaster Risk Sci. 11, 640-654. doi:10.1007/s13753-020-00300-y

Van de Vuurst, P., and Escobar, L. E. (2020). Perspective: Climate Change and the Relocation of Indonesia's Capital to Borneo. Front. Earth Sci. 8, 5. doi:10.3389/ feart.2020.00071

Walch, C. (2018). Typhoon Haiyan: Pushing the Limits of Resilience? the Effect of Land Inequality on Resilience and Disaster Risk Reduction Policies in the Philippines. Crit. Asian Stud. 50, 122-135. doi:10.1080/ 14672715.2017.1401936

Wang, J., Gao, W., Xu, S., and Yu, L. (2012). Evaluation of the Combined Risk of Sea Level Rise, Land Subsidence, and Storm Surges on the Coastal Areas of Shanghai, China. Climatic Change 115, 537-558. doi:10.1007/s10584-0120468-7

Wiering, M., Kaufmann, M., Mees, H., Schellenberger, T., Ganzevoort, W., Hegger, D. L. T., et al. (2017). Varieties of Flood Risk Governance in Europe: How Do Countries Respond to Driving Forces and what Explains Institutional Change?. Glob. Environ. Change 44, 15-26. doi:10.1016/ j.gloenvcha.2017.02.006

Xian, S., Yin, J., Lin, N., and Oppenheimer, M. (2018). Influence of Risk Factors and Past Events on Flood Resilience in Coastal Megacities: Comparative Analysis of NYC and Shanghai. Sci. Total Environ. 610-611, 1251-1261. doi:10.1016/ j.scitotenv.2017.07.229

Xu, C., Kohler, T. A., Lenton, T. M., Svenning, J.-C., and Scheffer, M. (2020). Future of the Human Climate Niche. Proc. Natl. Acad. Sci. USA 117, 11350-11355. doi:10.1073/pnas.1910114117

Yin, J., Yin, Z., Zhong, H., Xu, S., Hu, X., Wang, J., et al. (2011). Monitoring Urban Expansion and Land Use/land Cover Changes of Shanghai Metropolitan Area during the Transitional Economy (1979-2009) in China. Environ. Monit. Assess. 177, 609-621. doi:10.1007/s10661-010-1660-8

Yin, J., Yu, D., Yin, Z., Wang, J., and Xu, S. (2013). Modelling the Combined Impacts of Sea-Level Rise and Land Subsidence on Storm Tides Induced Flooding of the Huangpu River in Shanghai, China. Climatic Change 119, 919-932. doi:10.1007/s10584-013-0749-9

Yu, R., Zhai, P., and Chen, Y. (2018). Facing Climate Change-Related Extreme Events in Megacities of China in the Context of $1.5^{\circ} \mathrm{C}$ Global Warming. Curr. Opin. Environ. Sustainability 30, 75-81. doi:10.1016/j.cosust.2018.03.008

Zevenbergen, C., Fu, D. F., and Pathirana, A. (2018). Transitioning to Sponge Cities: Challenges and Opportunities to Address Urban Water Problems in China. Water 10, 1239. doi:10.3390/w10091230

Author Disclaimer: The views expressed herein are those of the authors and are not necessarily those of the Australian Government or Australian Research Council. This work contributes to Future Earth Coasts, a Global Research Project of Future Earth.

Conflict of Interest: The authors declare that the research was conducted in the absence of any commercial or financial relationships that could be construed as a potential conflict of interest.

Publisher's Note: All claims expressed in this article are solely those of the authors and do not necessarily represent those of their affiliated organizations, or those of the publisher, the editors and the reviewers. Any product that may be evaluated in this article, or claim that may be made by its manufacturer, is not guaranteed or endorsed by the publisher.

Copyright (ㄷ 2021 Nunn, Smith and Elrick-Barr. This is an open-access article distributed under the terms of the Creative Commons Attribution License (CC BY). The use, distribution or reproduction in other forums is permitted, provided the original author(s) and the copyright owner(s) are credited and that the original publication in this journal is cited, in accordance with accepted academic practice. No use, distribution or reproduction is permitted which does not comply with these terms. 